Article

\title{
Experimental Study on Co-Pyrolysis Characteristics of Household Refuse and Two Industrial Solid Wastes
}

\author{
Hancheng Ma ${ }^{1}$, Jianye Bei ${ }^{1}$, Mingxiu Zhan ${ }^{1,2}$, Wentao Jiao ${ }^{2}, \mathrm{Xu} \mathrm{Xu}{ }^{1, *}$ and Xiaodong $\mathrm{Li}^{3}$ \\ 1 College of Metrology and Measurement Engineering, China Jiliang University, Hangzhou 310018, China; \\ p1902085239@cjlu.edu.cn (H.M.); p1902085219@cjlu.edu.cn (J.B.); 17a0204144@cjlu.edu.cn (M.Z.) \\ 2 Research Center for Eco-Environmental Sciences, Chinese Academy of Sciences, Beijing 100085, China; \\ jiaowentao@rcees.ac.cn \\ 3 State Key Laboratory of Clean Energy Utilization, Institute for Thermal Power Engineering, Zhejiang \\ University, Hangzhou 310063, China; lixiaodong@cjlu.edu.cn \\ * Correspondence: xuxu@cjlu.edu.cn
}

Citation: Ma, H.; Bei, J.; Zhan, M.; Jiao, W.; Xu, X.; Li, X. Experimental Study on Co-Pyrolysis Characteristics of Household Refuse and Two Industrial Solid Wastes. Energies 2021, 14, 6945. https://doi.org/10.3390/ en14216945

Academic Editor: Antonis A. Zorpas

Received: 17 September 2021

Accepted: 14 October 2021

Published: 22 October 2021

Publisher's Note: MDPI stays neutral with regard to jurisdictional claims in published maps and institutional affiliations.

Copyright: (c) 2021 by the authors. Licensee MDPI, Basel, Switzerland. This article is an open access article distributed under the terms and conditions of the Creative Commons Attribution (CC BY) license (https:/ creativecommons.org/licenses/by/ $4.0 /)$.

\begin{abstract}
The calorific value of household refuse (HR) is greatly improved after classification, which includes the implementation of sufficient pyrolysis conditions. Therefore, a better pyrolysis effect can be achieved by co-pyrolysis with industrial solid waste (ISW) with high calorific value. In this work, HR and ISW were used as raw materials for co-pyrolysis experiments. The influence on the distribution of three-phase products after co-pyrolysis, the concentration of heavy metals and dioxins in the flue gas, and the distribution of PCDD/Fs isomers were studied. The results showed that, at a temperature of $600{ }^{\circ} \mathrm{C}$ and $\mathrm{H} / \mathrm{C}=1.3$, of the formed material, the quantity of pyrolysis gas was approximately $27 \mathrm{wt} . \%$, and the quantity of pyrolysis oil was approximately $40.75 \mathrm{wt} . \%$, which mainly contained alkanes, olefins, and aromatic hydrocarbons. When $\mathrm{S} / \mathrm{C}=0.008$, pyrolysis gas accounted for $25.95 \mathrm{wt} . \%$ of the formed material, and pyrolysis oil for $41.95 \mathrm{wt} . \%$ of the formed material. The ignition loss rate of pyrolysis coke was approximately $20 \%$, and the maximal calorific value was $14,217 \mathrm{KJ} / \mathrm{kg}$. According to the thermogravimetric experiment, the co-pyrolysis of $\mathrm{HR}$ and ISW can promote the positive reaction of pyrolysis, and the weight loss reached $62 \%$ at $550{ }^{\circ} \mathrm{C}$. The emission of gaseous heavy metals was relatively stable, and the concentration of heavy metals slightly decreased. The main heavy metals in the ash were $\mathrm{Cu}, \mathrm{Fe}$, and $\mathrm{Zn}$. The emission of dioxins could be effectively reduced by the pyrolysis of HR with ISW, and the produced dioxins were mainly synthesized from de novo synthesis. After pyrolysis, the toxic equivalent of dioxins in the flue gas was reduced from 0.69 to $0.29 \mathrm{ng}$ I-TEQ/ $\mathrm{Nm}^{3}$, and the distribution of dioxin isomers in the flue gas had little influence. The experimental results provide a theoretical basis for the application of co-pyrolysis technology with HR and ISW.
\end{abstract}

Keywords: household refuse; industrial solid waste; pyrolysis oil; dioxin; heavy metal; coke

\section{Introduction}

With economic development and the improvement of living standards, the production of household refuse (HR) is also increasing. In China, HR can generally be divided into four categories: recyclable refuse, kitchen refuse, hazardous refuse, and other refuse. In 2020, the volume of HR collected reached 242 million tons. In 2019, China's industrial solid waste (ISW), which is produced in industrial production activities, reached 3.53 billion tons, but the disposal amount was 8.78 billion tons, which is a large gap. Waste classification has been carried out in many cities in China. Garbage classification generally refers to a series of activities in which garbage is classified, stored, and transported according to certain regulations or standards, so as to be transformed into public resources. Waste classification can improve the resource value and economic value of waste and make the best use of everything; therefore, the calorific value is higher, and reached approximately 
$12,425 \mathrm{KJ} / \mathrm{kg}$ in 2019. Among new methods of HR treatment, pyrolysis is the most effective and promising method [1], having fewer sulfur oxides, nitrogen oxides, and other conventional pollutants, as well as fewer dioxins [2]. In addition, pyrolysis gas, pyrolysis oil, and coke from HR pyrolysis can be reused. Therefore, pyrolysis is gradually replacing traditional treatment methods [3]. In addition, due to the interaction of various components, better pyrolysis efficiency and pyrolysis oil can be obtained during the co-pyrolysis of multiple components [4-6]. Therefore, the co-pyrolysis of HR and ISW can both improve pyrolytic efficiency and provide a new method for the disposal of HR and ISW.

Previous studies on the co-pyrolysis of a variety of substances found that temperature, pyrolysis time, and the catalyst all have an impact on co-pyrolysis. Differently from incineration, pyrolysis can, not only produce a variety of products, such as combustible gas, oil, and coke, but also reduce the generation of pollutants such as $\mathrm{NO}_{\mathrm{X}}, \mathrm{CO}$, and dioxin [7-11]. It has many advantages, such as energy savings, a high resource recovery rate, wide adaptability, large treatment capacity, and low environmental pollution, which is in line with the concept of energy conservation and emission reduction. Wang et al. [12] co-pyrolyzed sludge and cotton stalks at $650{ }^{\circ} \mathrm{C}$ and found that adding more cotton stalks effectively reduced the migration and bioavailability of heavy metals in the biochar. A higher mixing ratio greatly decreased the total contents of heavy metals in the biochar and effectively immobilized those heavy metals. The co-pyrolysis of waste rubber and plastics in a tubular furnace was studied by Li et al. [13]. Their research found that, when adding $10 \%$ stalk additive at a rubber-to-plastics ratio of 4:1, a higher oil yield was achieved, which was increased by $10.3 \mathrm{wt} . \%$, and during which the heating value of the pyrolysis oil reached $39.93 \mathrm{MJ} \mathrm{kg}^{-1}$. Hossain et al. [14] co-pyrolyzed solid tire waste and rice husks in a fixed-bed co-pyrolysis reactor at $450{ }^{\circ} \mathrm{C}$ and found that the maximal liquid yield of a $50 \%$ tire and $50 \%$ rice husk mixture was $52 \mathrm{wt} . \%$. The results show that it is possible to obtain liquid products equivalent to petroleum fuel and valuable chemical raw materials from the selected waste if the pyrolytic conditions are appropriately selected. Previous studies mainly focused on the pyrolysis of pure substances; however, the components of domestic and industrial solid waste are complex, and the product distribution and pollutant emissions in the co-pyrolytic process are not yet clear. In particular, there are many chlorine-containing substances in domestic waste that may produce dioxins with high toxicity during heat treatment.

Therefore, in this paper, HR and ISW produced by the paper (ISW1) and rubber (ISW2) industries were used as raw materials for co-pyrolysis. The characteristics of HR and ISW products, and the emission characteristics of dioxins in pyrolysis flue gas, were studied under different ratios of $\mathrm{H} / \mathrm{C}$ and $\mathrm{S} / \mathrm{C}$.

\section{Materials and Methods}

\subsection{Materials}

A previous investigation found that the ISW of the paper and rubber industries contained high contents of carbon and sulfur, respectively, which can improve the quality of pyrolysis products and reduce the concentration of dioxin. Therefore, HR and ISW were used as raw materials for co-pyrolysis. The raw material was crushed into a powder with an average particle size of $0.30 \mathrm{~mm}$. Analysis was carried out in accordance with the proximate analysis of coal (GB/T212-2008) and the determination of chlorine in coal (GB/T3558-1996).

The results of the composition of household waste and the ultimate (including water content (M), ash (A), volatile matter (V), and fixed carbon (FC)) and proximate analyses of the raw materials are shown in Tables 1 and 2. After waste classification and waste-site sorting and drying, plastics accounted for $41.7 \%$ of the HR components, which accounted for a higher proportion than that before classification. In addition, the content of kitchen waste was lower. Therefore, the calorific value of $\mathrm{HR}$ could reach $17.031 \mathrm{MJ} / \mathrm{kg}$. The proportion of chlorine in the HR, ISW 1 , and ISW2 was $0.89 \%, 0.04 \%$, and $0.01 \%$, respectively. Organic and inorganic chlorine in $\mathrm{HR}$ are the main sources of $\mathrm{Cl}_{2}$ and $\mathrm{HCl}$ in flue gas. In the process of co-pyrolysis, chlorine is easily precipitated. When the temperature reaches $600{ }^{\circ} \mathrm{C}$, the chlorine precipitation rate is generally more than $70-80 \%$, which increases 
the volatility of metals and is a key element for dioxin formation $[15,16]$. The proportion of sulfur in the HR, ISW1, and ISW2 was $0.7 \%, 0.07 \%$, and $2.06 \%$, respectively. In the process of co-pyrolysis, sulfur in HR and ISW mainly exists in the form of organic and inorganic sulfur [17].

Table 1. Composition of household waste as a percentage (dry basis).

\begin{tabular}{cccccccc}
\hline Group & $\begin{array}{c}\text { Kitchen } \\
\text { Waste }\end{array}$ & Plastics & Paper & Textile & Wood & Metal & Others \\
\hline $\begin{array}{c}\text { Content } \\
(\%)\end{array}$ & 13.5 & 41.7 & 22.1 & 14.2 & 7.2 & 0.2 & 1.1 \\
\hline
\end{tabular}

Table 2. Ultimate and proximate analyses of raw materials.

\begin{tabular}{|c|c|c|c|c|c|c|c|c|c|c|c|c|}
\hline \multirow{2}{*}{ Sample } & \multicolumn{4}{|c|}{$\begin{array}{c}\text { Proximate Analysis } \\
\text { (Mass\%, As-Received Basis) }\end{array}$} & \multicolumn{2}{|c|}{ Qnet.ad } & \multicolumn{6}{|c|}{ Ultimate Analysis (Mass\%, Air-Dried Basis) } \\
\hline & M\% & $A \%$ & V\% & FC\% & $\mathrm{MJ} / \mathrm{kg}$ & kcal/kg & Cad\% & Had $\%$ & Nad $\%$ & Stad\% & Oad\% & Clad $\%$ \\
\hline ISW1 & 10.21 & 25.06 & 39.56 & 25.17 & 14.69 & 3511 & 39.22 & 3.29 & 1.03 & 0.07 & 31.33 & 0.04 \\
\hline ISW2 & 1.45 & 61 & 7.32 & 29.62 & 37.48 & 8957 & 84.71 & 5.46 & 0.78 & 2.06 & - & 0.01 \\
\hline HR & 21.62 & 35.51 & 31.24 & 11.63 & 17.03 & 4068 & 39.46 & 4.96 & 0.881 & 0.7 & 15.48 & 0.89 \\
\hline
\end{tabular}

\subsection{Experimental Procedures}

The co-pyrolysis furnace used in this experiment is shown in Figure 1. Co-pyrolysis took place in a continuous feed-type pyrolysis furnace, which mainly consisted of a carrier gas supply, a pyrolysis furnace chamber, a heating and temperature control system, and a condensing and collecting device. HR and ISW were pyrolyzed in the pyrolysis chamber, which was heated by electric heating modules and centrally controlled by the control cabinet. In this experiment, in order to ensure a constant pyrolysis atmosphere, after the material entered the feeder, the top diaphragm was closed. The baffle moved at a uniform speed to ensure the continuous falling of materials. In the process of waste falling into the furnace, part of the water was removed when it passed through the heating section of the upper part of the furnace. When it dropped to the bottom, it started to pile up and pyrolyze. The generated pyrolysis gas and oil entered the collection and condensation section through the upper inlet opening. In order to prevent the pyrolysis oil from condensing on the wall, a heating module was installed on the upper part of the furnace body and the flue gas pipeline. The pyrolysis oil was collected by the oil collector after condensation on the pipeline, and the pyrolysis gas was discharged from the tail after condensation. The pyrolysis chamber was equipped with two air intakes that could adjust the ratio of pyrolysis gas to air to meet the experimental requirements of the different pyrolysis and gasification atmospheres. A flue gas sampling tube was set in the cavity that could collect the gas produced in the furnace. Ice water circulated through the interlayer of the condensing tube to cool the flowing pyrolytic gas and to collect the pyrolytic oil condensing from the gas. High-purity nitrogen gas was selected as the carrier gas.

\subsection{Experiment Steps}

HR and ISW were mixed in different proportions, and the mass fractions of HR in the sample were 100,80 , and $70 \mathrm{wt}$. \%. The mass of each sample was approximately $1 \mathrm{~kg}$. First, a $1 \mathrm{~kg}$ sample was placed in a feeder and purged with $2 \mathrm{~L} / \mathrm{min}$ nitrogen for $30 \mathrm{~min}$, while heating it at a rate of $10{ }^{\circ} \mathrm{C} / \mathrm{min}$. After heating, the nitrogen flow rate was adjusted to $1 \mathrm{~L} / \mathrm{min}$. HR and ISW were pyrolyzed in the pyrolysis furnace body; the temperature was controlled at 500,600, and $700{ }^{\circ} \mathrm{C}$, and maintained for $60 \mathrm{~min}$. The specific working conditions are shown in Table 3. Groups A, B, E, F, and G were used to study the copyrolytic characteristics under different $\mathrm{H} / \mathrm{C}$ and $\mathrm{S} / \mathrm{C}$ ratios. Groups $\mathrm{B}, \mathrm{C}$, and D were used to study the effect of different temperature levels on co-pyrolysis. 


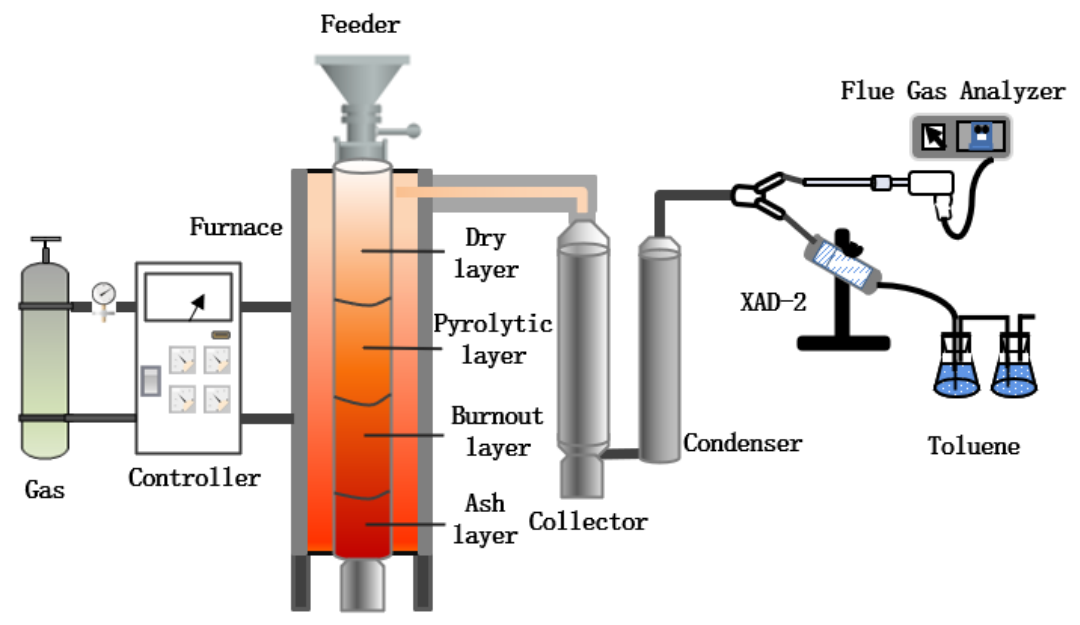

Figure 1. Schematic diagram of the pyrolysis furnace.

Table 3. Experimental conditions.

\begin{tabular}{ccccc}
\hline Group & Reactant & H/C & S/C & Temperature ${ }^{\circ} \mathbf{C}$ \\
\hline A & HR(100\%) & 1.6 & 0.006 & 600 \\
B & HR:ISW1 $=7: 3$ & 1.3 & 0.004 & 600 \\
C & HR:ISW1 $=7: 3$ & 1.3 & 0.004 & 700 \\
D & HR:ISW1 $=7: 3$ & 1.3 & 0.004 & 500 \\
E & HR:ISW1 $=8: 2$ & 1.4 & 0.005 & 600 \\
F & HR:ISW2 $=7: 3$ & 1.15 & 0.008 & 600 \\
G & HR:ISW2 $=8: 2$ & 1.25 & 0.007 & 600 \\
\hline
\end{tabular}

The pyrolysis oil was condensed by the pipeline and collected by the oil collector. After condensation, the pyrolysis gas was discharged. The flue gas was sampled for approximately $1 \mathrm{~h}$ during each sampling, using the constant-speed sampling principle, and flue gas was produced through the membrane and XAD-2 resin, respectively. The toluene solution was placed in an ice bath. In order to ensure the accuracy and stability of the experimental results, each test was carried out in duplicate. At the end of the experiment, samples containing XAD-2 resin, toluene solution, and reaction residue were collected, and their pipes were also collected after being washed with dichloromethane, acetone, and toluene, respectively. Collected samples were sent to the laboratory for lowtemperature storage. The pyrolysis coke and pyrolysis oil were collected and stored for subsequent analysis.

In addition, a thermogravimetric analysis of HR and ISW was carried out by using a thermogravimetric analyzer (TGA); $\mathrm{HR}, \mathrm{ISW}$, and their mixtures were used as raw materials. The temperature was increased from 25 to $850^{\circ} \mathrm{C}$ at a heating rate of $10^{\circ} \mathrm{C} / \mathrm{min}$. Thermal gravity (TG) and derivative thermogravimetry (DTG) curves were obtained by collecting and analyzing the data. Then, $99.9 \%$ high-purity nitrogen with a flow rate of $50 \mathrm{~mL} / \mathrm{min}$ was used as the carrier gas to ensure an inert atmosphere during operation.

\subsection{Detection Method}

According to the USAEPA1613 method [18], dioxin samples were pretreated and analyzed by high-resolution gas chromatography/high-resolution mass spectrometry (HRGC/HRMS, JMS8000D, JEOL). The toxicity equivalent (TEQ) was calculated using the international NATO/CCMS factor, namely I-TEQ [19]. The average recoveries of PCDD/Fs ranged from $55 \%$ to $125 \%$, which were within the quality control range.

The GB 16889-2008 landfill pollution control standard (life) of the HJ/T300-2007 leaching procedure (solid-waste leaching toxicity of the acetate buffer method) was used to test the leaching toxicity. A liquid/solid ratio of $20: 1(\mathrm{~mL} / \mathrm{g})$ was added to the leach sample at a $\mathrm{pH}$ of $2.64 \pm 0.05$ and a speed of $30 \pm 2$ revolutions $/ \mathrm{min}$, at room temperature 
$\left(23 \pm 2{ }^{\circ} \mathrm{C}\right)$, rotating $(18 \pm 2 \mathrm{~h})$. Lastly, the concentration of heavy metals in the filtrate was determined by ICP-AES (ICAP6300). The chlorine content in the samples was determined by high-temperature hydrolysis and ion chromatography (ICS-6000, Thermo, China).

\section{Results and Discussion}

\subsection{Pyrolysis Characteristics}

Figure 2a shows that the pyrolytic process of HR can be divided into three main stages. In the first stage $\left(100-300{ }^{\circ} \mathrm{C}\right)$, the TG curve presented the first weight loss peak, with a weight loss rate of $8.3 \%$. This part mainly included water drying and the decomposition of less stable polymers $[20,21]$. In the second stage $\left(300-600{ }^{\circ} \mathrm{C}\right)$, the second weight loss peak appeared on the TG curve, which was the main pyrolytic stage of HR, and the weight loss rate was approximately $30.21 \%$. In the third stage $\left(500-800^{\circ} \mathrm{C}\right)$, the TG curve presented a third weight loss peak with a weight loss rate of $11.3 \%$, which was mainly due to the pyrolysis of heavy components, such as long-chain refractory organic macromolecules.

Figure 2b,c show the TG/DTG curves of the thermal decomposition of ISW1 and ISW2, respectively. Figure $2 \mathrm{~b}$ shows that weight loss began around $300{ }^{\circ} \mathrm{C}$, and a significant weight loss peak appeared around $440{ }^{\circ} \mathrm{C}$, with a weight loss rate of $58.5 \%$, which was mainly due to the decomposition of organic matter in ISW1. The weight loss rate decreased significantly when the temperature rose to approximately $500{ }^{\circ} \mathrm{C}$, the weight loss curve became flat after $550{ }^{\circ} \mathrm{C}$, and pyrolysis ended. Figure $2 \mathrm{c}$ shows that the pyrolytic trends of ISW 2 and ISW 1 were roughly the same. Weight loss began at $250{ }^{\circ} \mathrm{C}$ and the weight loss rate was approximately $56.8 \%$ at $450{ }^{\circ} \mathrm{C}$.

Figure $2 \mathrm{a}-\mathrm{c}$ show that there was a large difference between the pyrolytic characteristics of HR and ISW. ISW was pyrolyzed in a relatively narrow temperature range $\left(300-500{ }^{\circ} \mathrm{C}\right)$, while HR was pyrolyzed in a wider temperature range $\left(200-850^{\circ} \mathrm{C}\right)$, because of its complex components. This was mainly due to the fact that the composition of ISW was relatively simple and there was no long-chain refractory materials that could be rapidly pyrolyzed at a low temperature.

Figure 2d,e shows the TG/DTG characteristic pyrolytic curves of HR and ISW1 mixed at a 7:3 ratio. The TG curve after mixed ISW1 pyrolysis had a larger weight loss ratio than that of each component alone, reaching approximately $62 \%$ in the main weight loss stage. At $600-800{ }^{\circ} \mathrm{C}$, the total weight loss reached approximately $70 \%$, which indicated that the co-pyrolysis of HR and ISW1 could effectively improve the pyrolytic efficiency. When HR and ISW2 were mixed, the weight loss rate was less than that of HR and ISW1, which reached $55.2 \%$ at $800{ }^{\circ} \mathrm{C}$.

\subsection{Analysis of Co-Pyrolytic Products}

The yields of pyrolysis gas, pyrolysis oil, and coke are shown in Figure 3. According to Groups B, C, and D, with an increase in temperature, volatiles in the liquid phase were further pyrolyzed, resulting in more gas than liquid. With the increase in temperature from 500 to $700{ }^{\circ} \mathrm{C}$, the yield of pyrolysis oil first increased from $39.35 \%\left(\mathrm{D}, 500{ }^{\circ} \mathrm{C}\right)$ to $40.75 \%\left(\mathrm{~B}, 600^{\circ} \mathrm{C}\right)$, and finally decreased to $35.15 \%\left(\mathrm{C}, 700^{\circ} \mathrm{C}\right)$. This may have been due to incomplete pyrolysis and the low yield of pyrolysis oil at a low temperature $\left(500{ }^{\circ} \mathrm{C}\right)$. As the temperature rose to $600^{\circ} \mathrm{C}$, the pyrolytic efficiency was improved, which was due to the yield of pyrolysis oil increasing. As the temperature continued to rise to $700{ }^{\circ} \mathrm{C}$, part of the pyrolysis oil was converted into gas, and the yield of pyrolysis oil decreased. According to the temperature control group (B, C, and D), the co-pyrolysis of HR and ISW occurred most effectively at $600{ }^{\circ} \mathrm{C}$, so the follow-up experiment was carried out at $600{ }^{\circ} \mathrm{C}$. 


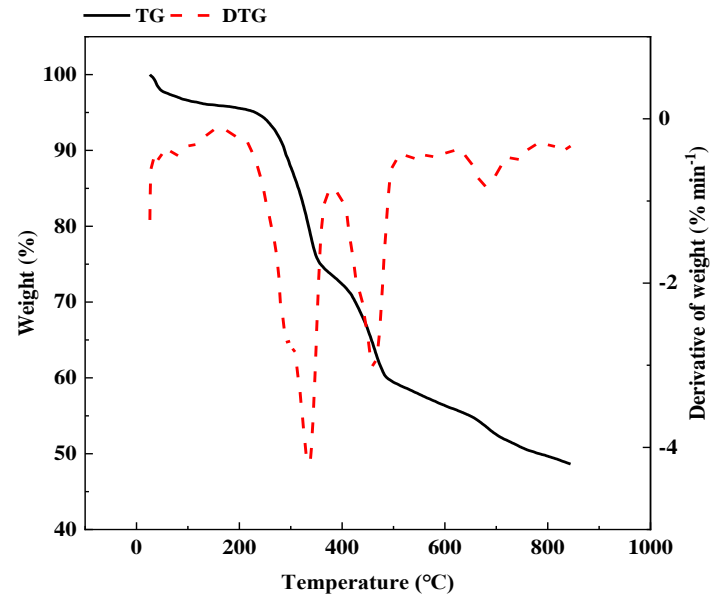

(a)

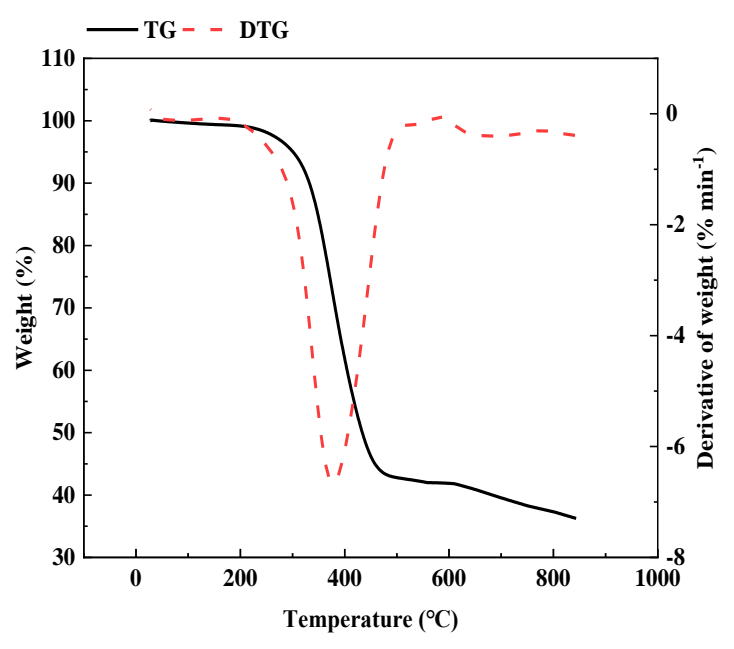

(c)

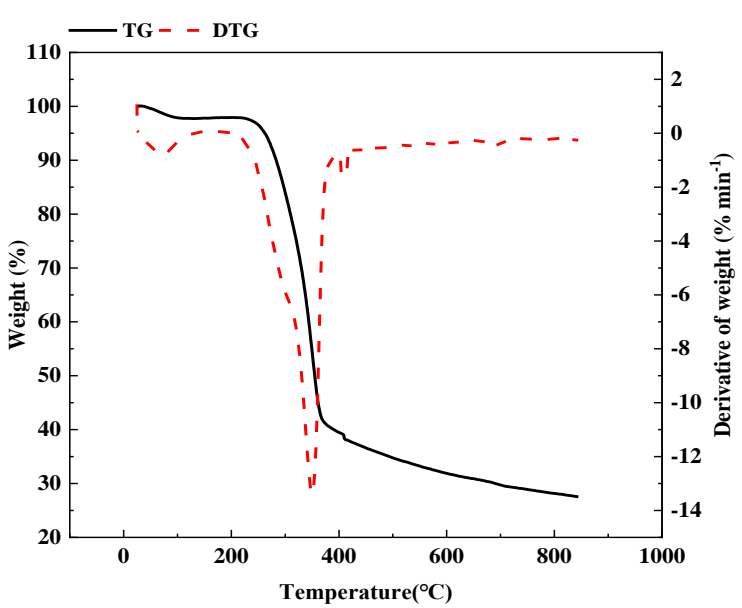

(b)

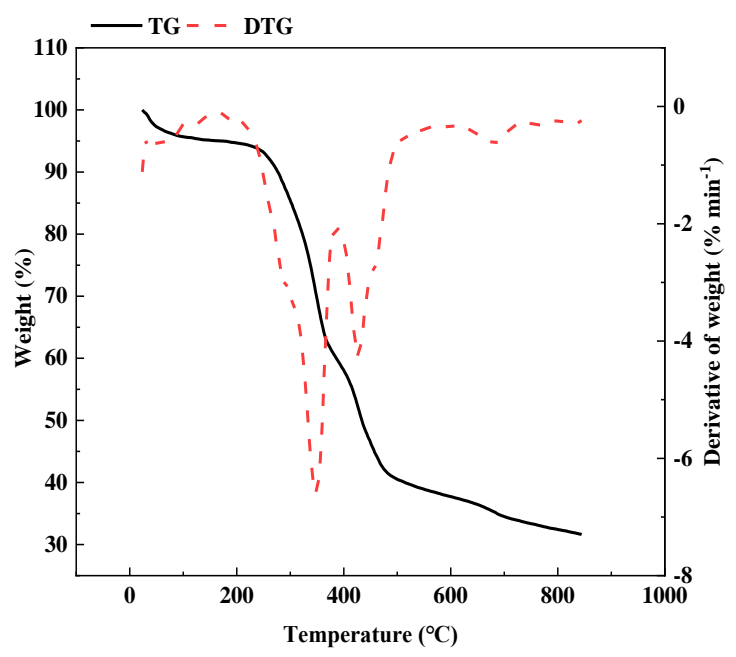

(d)

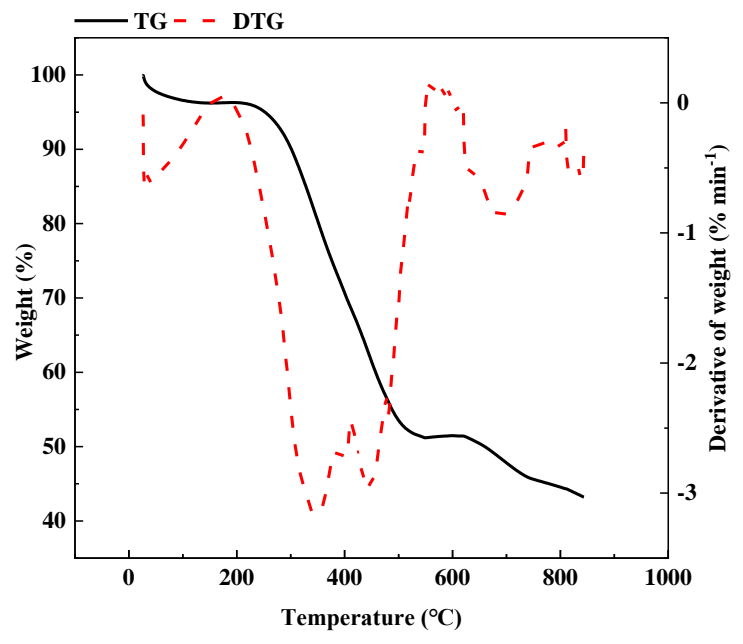

(e)

Figure 2. Thermal gravity (TG) and differential TG (DTG) curves of (a) HR, (b) ISW1, (c) ISW2, (d) HR and ISW1, (e) HR and ISW2. 


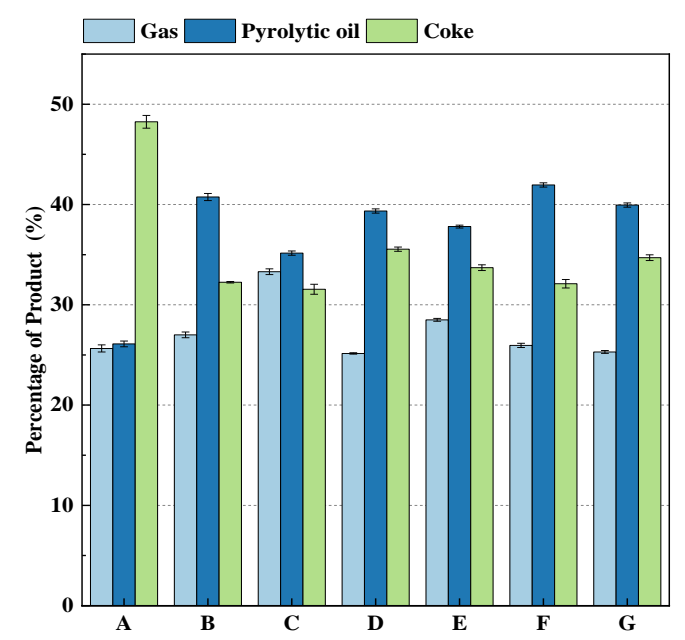

Figure 3. Product yield of co-pyrolysis from HR and ISW for Groups A-G.

Compared with HR pyrolysis (A) alone, HR and ISW1 co-pyrolysis (E) reduced the coke yield from $48.25 \%$ to $37.8 \%$. The yield of pyrolysis gas and oil increased by $2.85 \%$ and $11.7 \%$, respectively, which showed that the co-pyrolysis of HR and ISW1 was beneficial to the occurrence of a pyrolytic reaction and the formation of light molecules. Compared with Groups A, B, and E, with the decrease in the $\mathrm{H} / \mathrm{C}$ ratio, the yield of pyrolysis oil increased from $37.8 \%$ to $40.75 \%$, and the content of coke slightly decreased. Similar results were obtained for Groups A, F, and G. This may have been due to the decrease in the $\mathrm{H} / \mathrm{C}$ ratio in the raw materials, which promoted the co-pyrolytic process. It may have also been because some components of HR and ISW2 reacted with one another to promote co-pyrolysis.

The S/C ratio also had a similar effect on the co-pyrolysis of HR and ISW. The copyrolysis of HR and ISW2 had a higher oil production rate than that of HR and ISW1, which may have been because there were more organic compounds in rubber, which are conducive to the formation of pyrolysis oil. In Groups A, F, and G, with the decrease in the $\mathrm{S} / \mathrm{C}$ ratio, the yield of pyrolysis gas and oil slightly decreased, and the proportion of coke slightly increased, which was similar to the co-pyrolytic trend of HR and ISW1, indicating that the S/C ratio had little effect on the yield of co-pyrolytic products.

Alkanes, alkenes, and aromatics were the main components of pyrolysis oil. Different feedstocks and temperatures changed the co-pyrolytic conditions, thus changing the distribution of oil products to varying degrees. As shown in Figure 4, when HR and ISW1 were co-pyrolyzed and the temperature was increased from 500 to $700{ }^{\circ} \mathrm{C}$ (Groups D, B, and C), the alkene content increased from $14 \%$ to $25.6 \%$, the aromatic content increased from $19.5 \%$ to $41.2 \%$, and the alkane content decreased from $66.5 \%$ to $55.4 \%$. By increasing the $\mathrm{H} / \mathrm{C}$ ratio (Groups $\mathrm{A}, \mathrm{B}$, and $\mathrm{E}$ ) of the pyrolytic feedstock, the yield of olefins also increased to a certain extent, but it was lower than that of HR pyrolysis alone. This may have been due to a mutual reaction between materials caused by co-pyrolysis, which promoted the decomposition of olefins into alkanes. With the increase in the $\mathrm{H} / \mathrm{C}$ ratio, the production of aromatics decreased from $28 \%$ to $22.5 \%$. When HR and ISW2 were co-pyrolyzed, with the increase in the S/C ratio, the alkene content increased from $24.3 \%$ to $31.1 \%$, while the amount of alkanes and aromatics decreased. In conclusion, when the temperature was between 600 and $700{ }^{\circ} \mathrm{C}$, more pyrolysis oil could be produced from HR and ISW co-pyrolysis. When the $\mathrm{H} / \mathrm{C}$ and $\mathrm{S} / \mathrm{C}$ ratios were 1.3 and 0.007 , respectively, more pyrolysis oil containing olefin could be obtained. 


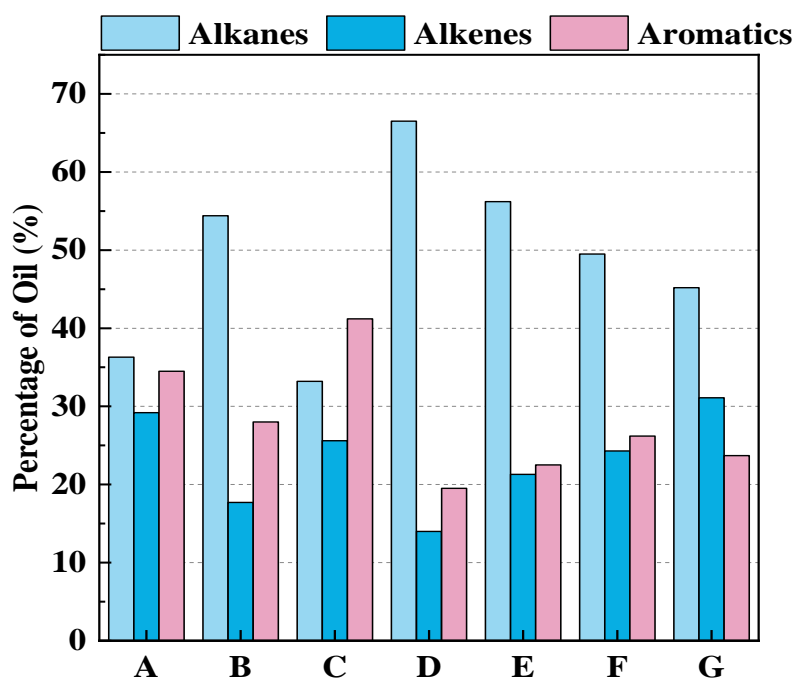

Figure 4. Content of alkanes, alkenes, and aromatics in pyrolysis oils for Groups A-G.

The ignition loss and calorific value of pyrolytic coke are shown in Table 4 . When HR and ISW1 co-pyrolyzed, the lowest coke ignition loss rate was $16.2 \%$ (C), which was due to the further pyrolysis of coke at a higher temperature. The highest ignition loss rate was $34.1 \%$, because of the low temperature. At a low temperature, coke was the main pyrolytic product, and carbon was mainly found in solid form. When HR and ISW2 co-pyrolyzed, the ignition loss was $41.9 \%$, which was much higher than that of co-pyrolyzed HR and ISW1. Compared with HR pyrolysis alone, co-pyrolyzed coke had a higher calorific value. Therefore, co-pyrolyzed coke could be recycled, which is conducive to improving energy utilization.

Table 4. Ignition loss rate and calorific value of coke.

\begin{tabular}{ccc}
\hline Group & Loss of Ignition (\%) & Calorific Value (KJ/kg) \\
\hline A & 21.2 & 5260 \\
B & 32.2 & 9496 \\
C & 16.2 & 4486 \\
D & 34.1 & 11,513 \\
E & 24.6 & 6131 \\
F & 41.9 & 14,217 \\
G & 39.6 & 13,561 \\
\hline
\end{tabular}

\subsection{Pollutant Analysis}

\subsubsection{Emission Characteristics of Heavy Metals}

Heavy metals mainly exist in the form of oxides, mineral salts, sulfides, and hydroxides in HR and ISW. Mineral salts and hydroxides are usually converted into oxides or sulfides with better thermal stability during pyrolysis. During co-pyrolysis, due to the characteristics of heavy metals (such as their boiling point), HR composition (chlorine, sulfur, alkali metal content, etc.), and the operating environment in the furnace (i.e., the temperature, time, atmosphere, and catalyst), heavy metals are found in the form of oxides and mineral salts. After the evaporation and condensation process, mineral salts and hydroxides are usually converted into oxides or sulfides with good thermal stability [22,23]. Heavy metals are also important catalysts for the synthesis of dioxins; however, when the amount of heavy metals used as catalysts meets the requirements of a catalytic reaction, the increase in heavy metals has no effect on the reaction rate, and cannot increase the amount of dioxins and their precursors [24].

The emission characteristics of the heavy metals in flue gas in this experiment, under different working conditions, are shown in Table 5. Comparing various working conditions revealed that the emission of gaseous heavy metals was relatively stable. During co- 
pyrolysis, the concentration of heavy metals decreased slightly, and only Ni emissions increased, but the change range was within one order of magnitude. With the temperature increasing from 500 to $700{ }^{\circ} \mathrm{C}$, the content of $\mathrm{Cu}$ in the heavy metals decreased from 0.1122 to $0.0136 \mathrm{mg} / \mathrm{L}$, and the amount of Fe decreased from 0.3572 to $0.2478 \mathrm{mg} / \mathrm{L}$. In general, due to the lack of a catalyst, the content of heavy metals in flue gas was relatively stable $[25,26]$. The co-pyrolysis of HR and ISW generally had little effect on the emission of heavy metals in the gas, and did not aggravate the emission of heavy metals. Additionally, heavy metals may be more easily absorbed by coke, so the heavy metal content in coke should be closely monitored.

Table 5. Concentrations of heavy metals in flue gas (mg/L) for Groups A-G.

\begin{tabular}{ccccccccc}
\hline \multirow{2}{*}{ Group } & \multicolumn{7}{c}{ Concentration (mg/L) } \\
\cline { 2 - 9 } & As & Cd & Cr & Cu & Fe & Ni & Pb & Zn \\
\hline A & 0.0008 & 0.0016 & 0.0142 & 0.0303 & 0.3486 & 0.0053 & 0.2716 & 0.3701 \\
B & 0.0017 & 0.0029 & 0.0118 & 0.0296 & 0.3411 & 0.0061 & 0.2524 & 0.2956 \\
C & 0.0002 & 0.0008 & 0.0116 & 0.0136 & 0.2478 & 0.0051 & 0.1923 & 0.0339 \\
D & 0.0167 & 0.0005 & 0.0093 & 0.1122 & 0.3572 & 0.0027 & 0.0084 & 0.1824 \\
E & 0.0042 & 0.0007 & 0.0107 & 0.0062 & 0.1903 & 0.0079 & 0.0017 & 0.0239 \\
F & 0.0039 & 0.0001 & 0.0089 & 0.0063 & 0.1924 & 0.0008 & 0.0017 & 0.0342 \\
G & 0.0094 & 0.0004 & 0.0118 & 0.0089 & 0.5238 & 0.0109 & 0.0045 & 0.0573 \\
\hline
\end{tabular}

The heavy metal contents in the coke are shown in Table 6. Except for $\mathrm{Cu}, \mathrm{Fe}$, and $\mathrm{Zn}$, the other heavy metals hardly changed. The content of $\mathrm{Cu}$ in coke was 2050.4 $\mathrm{mg} / \mathrm{kg}$ at $100 \mathrm{wt} . \%$ of HR. Then, the content was reduced to $149.7 \mathrm{mg} / \mathrm{kg}$ when $30 \mathrm{wt} . \%$ ISW1 was added. In Groups B-D, with the increase in temperature, the $\mathrm{Cu}$ decreased from 310.6 to $149.72 \mathrm{mg} / \mathrm{kg}$, and then increased to $207.75 \mathrm{mg} / \mathrm{kg}$. Fe showed a similar trend. The increase in temperature may have reduced the formation of heavy metals, but when the temperature was higher, the volatilization of chlorine promoted the formation of heavy metals. When HR and ISW2 were co-pyrolyzed, the concentration of heavy metals was higher than that in HR and ISW1, which showed that, in practical applications, much more attention should be paid to the emission of heavy metals.

Table 6. Heavy metal content in coke for Groups A-G.

\begin{tabular}{ccccccccc}
\hline \multirow{2}{*}{ Group } & \multicolumn{8}{c}{ Concentration $(\mathbf{m g} / \mathbf{k g})$} \\
\cline { 2 - 9 } & As & Cd & Cr & Cu & Fe & Ni & Pb & Zn \\
\hline A & 12.8 & 1.7 & 207.2 & 2050.4 & $14,563.9$ & 52.3 & 120.6 & 1823.1 \\
B & 12.2 & 0.2 & 85.4 & 149.7 & 8113.0 & 20.1 & 83.7 & 2427.6 \\
C & 5.5 & 1.2 & 80.0 & 207.8 & $13,173.1$ & 23.8 & 302.1 & 908.8 \\
D & 13.8 & 0.0 & 298.1 & 310.6 & $21,391.5$ & 58.3 & 197.1 & 2270.1 \\
E & 10.8 & 0.4 & 140.8 & 187.8 & 8323.3 & 22.7 & 82.4 & 1298.3 \\
F & 10.3 & 4.2 & 81.6 & 388.7 & 6425.5 & 62.2 & 125.3 & $46,721.1$ \\
G & 11.6 & 2.4 & 57.2 & 721.2 & 7321.6 & 23.5 & 53.9 & $34,451.6$ \\
\hline
\end{tabular}

\subsubsection{PCDD/Fs in Flue Gas}

The mass concentration of dioxins in flue gas during the co-pyrolysis of $\mathrm{HR}$ and ISW is shown in Figure 5a. When the raw material was 100\% HR (Group A), the mass concentration of PCDD/Fs in the flue gas after pyrolysis was $3.89 \mathrm{ng} / \mathrm{Nm}^{3}$, and when $30 \%$ of ISW1 was added (B), the PCDD/F concentration was reduced to $1.66 \mathrm{ng} / \mathrm{Nm}^{3}$. When the co-pyrolysis temperature was increased from 500 to $700{ }^{\circ} \mathrm{C}(\mathrm{C})$, the PCDD/F concentration in the flue gas after co-pyrolysis was increased from $42.8 \pm 1.26$ to $2.34 \mathrm{ng} / \mathrm{Nm}^{3}$. When the temperature was $500{ }^{\circ} \mathrm{C}$, the concentration of PCDD/Fs was higher, which may have been due to the relatively high content of heavy metals, which provided a metal catalyst for the formation of dioxin [27]. When HR:ISW2 = 7:3 (S/C = 0.08), the concentration of $\mathrm{PCDD} / \mathrm{Fs}$ was $12.4 \mathrm{ng} / \mathrm{Nm}^{3}$. When the mixing ratio was decreased to $8: 2(\mathrm{~S} / \mathrm{C}=0.07)$, the concentration of PCDD $/ \mathrm{Fs}$ was $21.2 \mathrm{ng} / \mathrm{Nm}^{3}$. This indicated that the lower $\mathrm{S} / \mathrm{C}$ ratio 
made it easier to generate PCDD/Fs [28]. Similarly to previous studies, the presence of sulfur could inhibit the formation of PCDD/Fs to a certain extent $[29,30]$. Concentrations were higher than those of HR and ISW1, because there were more carbon elements in ISW2, which provided a carbon source for the formation of dioxins [31]. A schematic diagram of the dioxin formation mechanism during pyrolysis is shown in Figure 6. The role of $\mathrm{SO}_{2}$ in pyrolysis is shown in Table 7 . It can be seen from the figure that $\mathrm{SO}_{2}$ reacts with $\mathrm{Cl}_{2}$ to produce $\mathrm{SO}_{3}$ and $\mathrm{HCl}$. This reduces the $\mathrm{Cl}_{2}$ involved in the chlorination of aromatic hydrocarbon precursors and reduces the production of dioxins at the source. In addition, $\mathrm{SO}_{2}$ reacts with $\mathrm{Cu}$ and other heavy metals to produce $\mathrm{CuSO}_{4}$, which consumes the heavy metals involved in de novo synthesis and reduces the generation of dioxins [16,32].

The toxic equivalent of dioxins in flue gas during the co-pyrolysis of HR and ISW is shown in Figure $5 \mathrm{~b}$. The toxic equivalent of dioxin in flue gas A was $0.69 \mathrm{ng} \mathrm{I}-\mathrm{TEQ} / \mathrm{Nm}^{3}$. After the addition of ISW1 (30\%), the toxicity equivalent of dioxin in the flue gas decreased to $0.29 \mathrm{ng}$ I-TEQ/ $\mathrm{Nm}^{3}$. This may have been due to the increase in the ratio of carbon to hydrogen during co-pyrolysis, which promoted the pyrolytic process and discharged more carbon in the form of short-chain hydrocarbons and $\mathrm{CO}$, reducing the carbon sources generated by dioxin [33]. When the temperature increased from 600 to $700{ }^{\circ} \mathrm{C}$, the concentration of dioxin in flue gas increased from 0.29 to $0.54 \mathrm{ng}$ I-TEQ/ $\mathrm{Nm}^{3}$, possibly because the temperature increased and the co-pyrolysis efficiency improved, which promoted PVC decomposition in the raw material and generated hydrogen chloride gas, which, in turn, promoted pyrolysis [34]. At the same time, chlorinated organic compounds formed by pyrolysis, such as chlorobenzene, participated in the formation of dioxins as precursors [35]. Chlorine in flue gas mainly exists in the form of HCI. Relevant experiments have shown that the chlorine source of $\mathrm{PCDD} / \mathrm{Fs}$ is $\mathrm{Cl}_{2}$, not $\mathrm{HCl}$, but it is easy for $\mathrm{HCl}$ to react with heavy metals such as $\mathrm{Cu}$ to produce $\mathrm{Cl}_{2}$ [36], which provides a chlorine source for the synthesis of dioxins [37-39].

The isomeric distribution of 17 toxic dioxins in pyrolysis flue gas is shown in Figure 7. PCDD/Fs in the flue gas of Group A were mainly distributed in PCDFs, in which the $2,3,7,8$-TCDF content was the highest, accounting for $49.27 \%$ and indicating that a de novo synthesis reaction was the main method of generating dioxins [40]. In Group B, PCDFs were still the main dioxins in the flue gas, but their proportion was reduced by $4 \%$ compared with Group A, indicating that the contribution of the precursor synthesis reaction to dioxin production was further reduced. After increasing the pyrolytic temperature (C), the dioxins found were mainly PCDFs, indicating that the increase in temperature had little effect on the formation of dioxin isomers and that de novo synthesis was still dominant. In the flue gas of Group A, the PCDDs were mainly 2,3,7,8-TCDD and OCDD, accounting for $72.6 \%$ of the total concentration of PCDDs, and the PCDFs were mainly $1,2,34,6,7,8-\mathrm{HPCDF}$ and OCDF, the sum of which reached $86.8 \%$. PCDDs in the flue gas of Groups B and C were still mainly 2,3,7,8-TCDD and OCDD, but their proportion was further increased compared with that of Group A. Therefore, the toxic equivalent was increased and PCDFs were mainly 2,3,7,8-TCDF. Compared with Groups A-C, the proportion of PCDFs in Group D was increased to approximately $88 \%$. When the S/C ratio decreased, the PCDF content increased to $92.95 \%$, indicating that the ratio of de novo synthesis was further increased. All in all, the distribution of dioxin isomers in the flue gas during co-pyrolysis was similar to that in the single-pyrolysis flue gas, indicating that the effect of co-pyrolysis on the distribution of dioxin isomers was minor. 


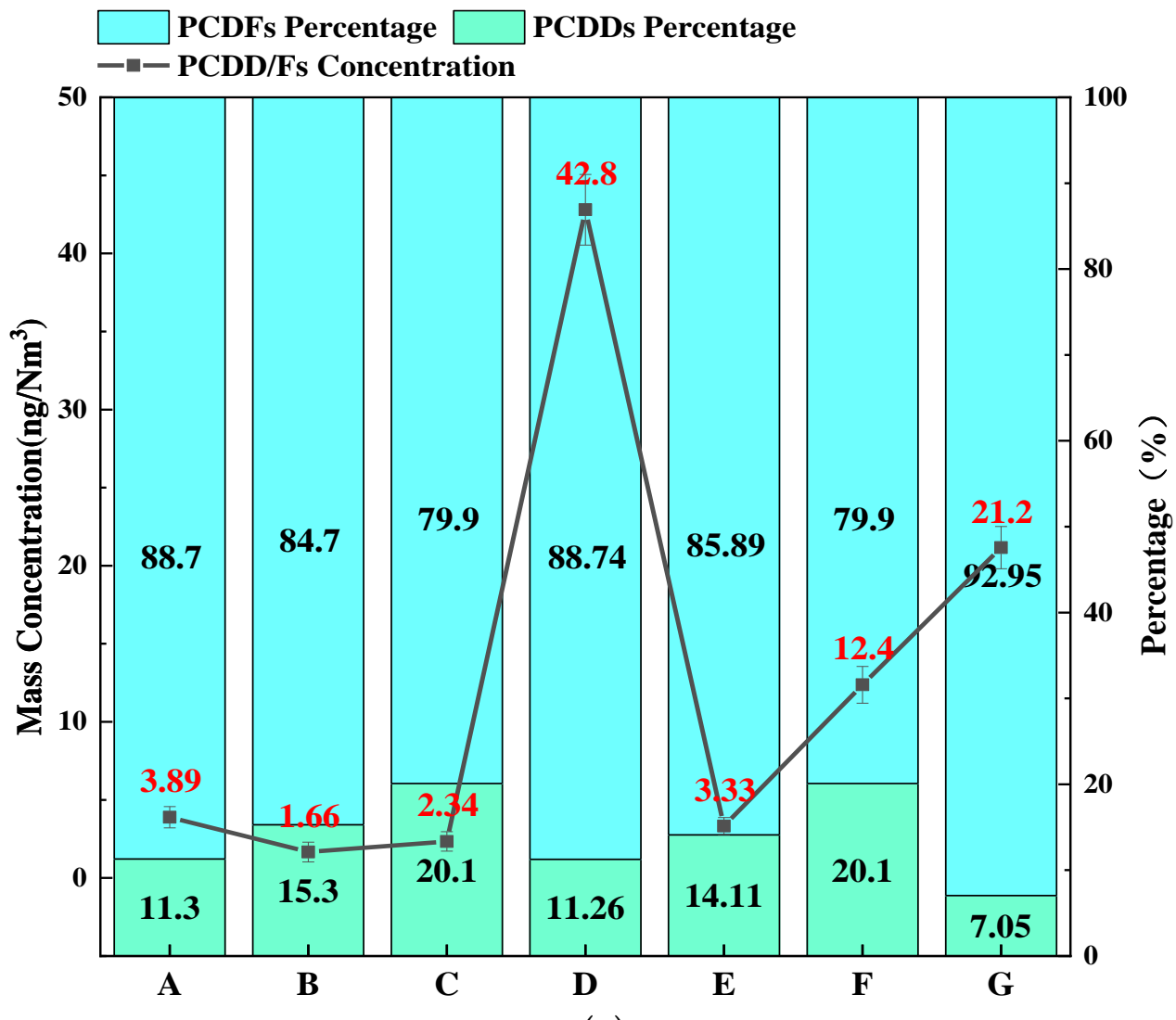

(a)

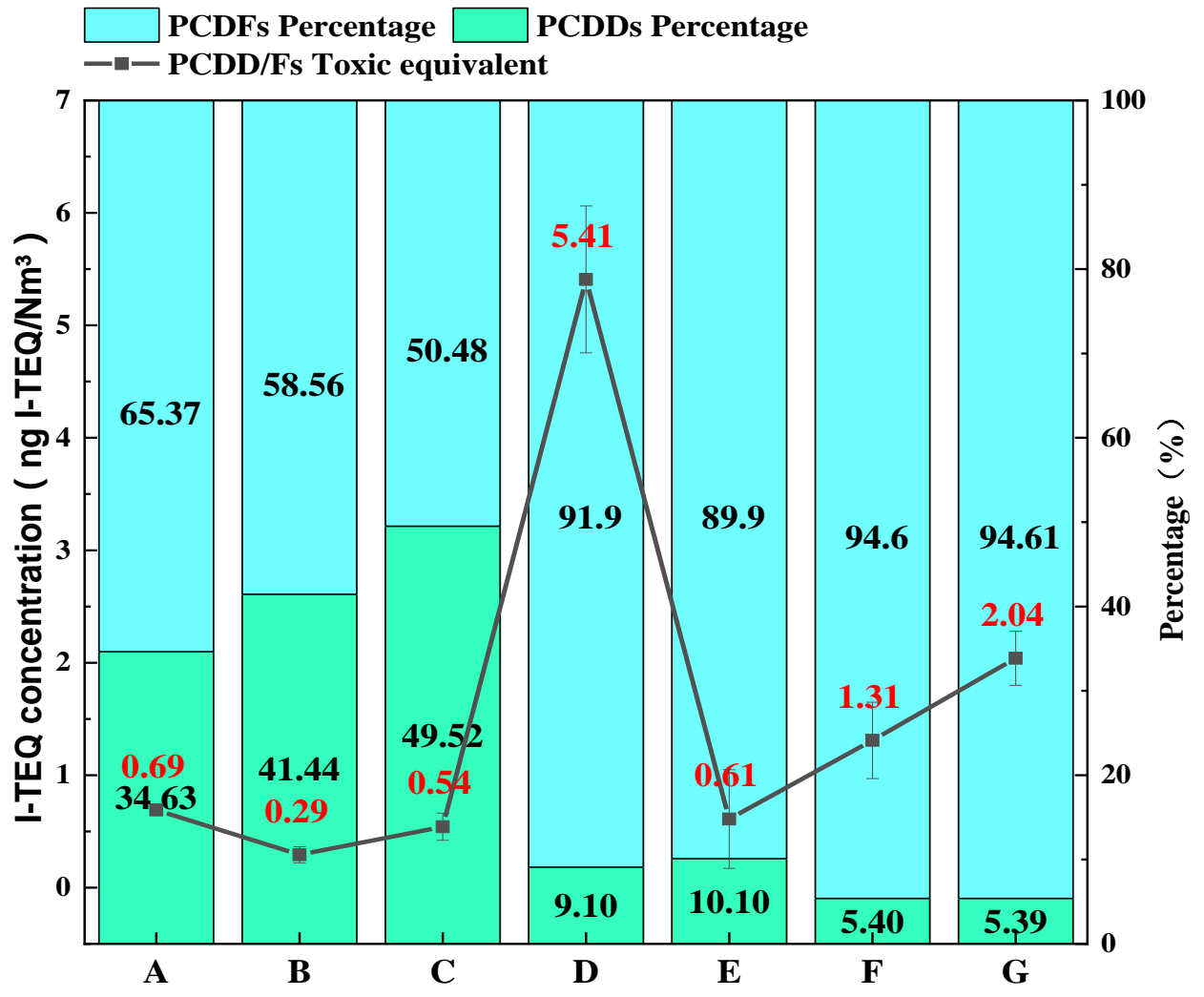

(b)

Figure 5. Concentration of PCDD/Fs in flue gas. (a) Concentration of dioxin in flue gas; (b) toxic equivalent of dioxin in flue gas. 


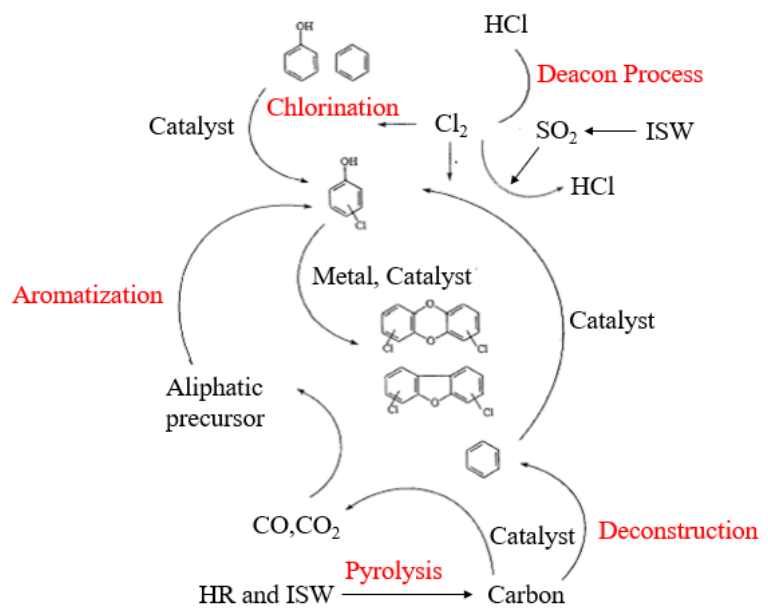

Figure 6. Pyrolysis dioxin formation model diagram.

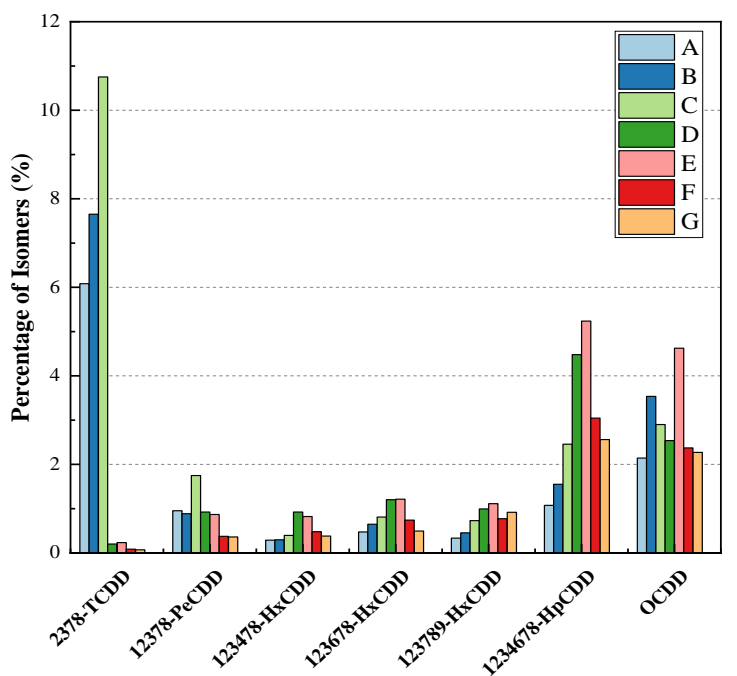

(a)

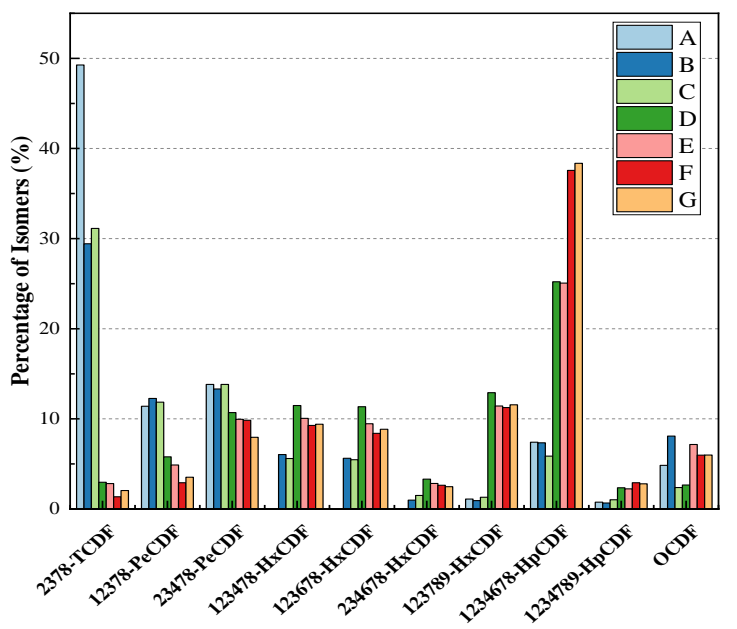

(b)

Figure 7. Distribution of the 17 dioxin isomers for Groups A-G. (a) Isomers of PCDDs, (b) isomers of PCDFs. 
Table 7. Reaction of sulfur with key elements in the synthesis of dioxin.

\begin{tabular}{cc}
\hline Number & Reaction Equation \\
\hline 1 & $\mathrm{Cl}_{2}+\mathrm{SO}_{2}+\mathrm{H}_{2} \mathrm{O} \rightarrow 2 \mathrm{HCl}+\mathrm{SO}_{3}$ \\
\hline 2 & $\mathrm{CuO}+\mathrm{SO}_{2}+1 / 2 \mathrm{O}_{2} \rightarrow \mathrm{CuSO}_{4}$ \\
\hline 3 & $\mathrm{SO}_{2}+\mathrm{CuCl}_{2}+\mathrm{H}_{2} \mathrm{O}+1 / 2 \mathrm{O}_{2} \rightarrow \mathrm{CuSO}_{4}+2 \mathrm{HCl}$ \\
\hline
\end{tabular}

\section{Conclusions}

From the co-pyrolytic experiment using HR and ISW, the following conclusions were drawn:

1. The HR and ISW co-pyrolytic product distribution was relatively uniform compared with HR pyrolysis alone. After mixing with the ISW, the coke yield decreased by approximately $14.6 \%$, and the pyrolysis gas and oil yields slightly increased. Pyrolysis oil took priority, with alkenes, alkanes, and aromatic hydrocarbons. The ignition loss rate of pyrolysis coke was approximately $20 \%$, and the maximal calorific value was $14,217 \mathrm{KJ} / \mathrm{kg}$.

2. The thermogravimetric experiment showed that the pyrolytic characteristics of HR and ISW differed greatly: ISW pyrolyzed at $300-500{ }^{\circ} \mathrm{C}$, while HR pyrolysis could be completed at $200-800{ }^{\circ} \mathrm{C}$. The co-pyrolysis of HR and ISW was able to promote the forward pyrolytic reaction, and the weight loss rate reached $62 \%$ at $550{ }^{\circ} \mathrm{C}$.

3. During the co-pyrolysis of HR and ISW, the emission of gaseous heavy metals was relatively stable, and the concentration of heavy metals was slightly reduced. HR and ISW co-pyrolysis could effectively reduce dioxin emissions, and the formation of $\mathrm{PCDD} / \mathrm{Fs}$ was mainly achieved via de novo synthesis. The toxic equivalent of dioxins in the flue gas after mixed pyrolysis decreased from 0.69 to $0.29 \mathrm{ng}$ I-TEQ/ $\mathrm{Nm}^{3}$. The higher S/C ratio could inhibit the formation of PCDD/Fs. After co-pyrolysis, the distribution of PCDD/Fs isomers in the flue gas had little effect, and PCDFs were the main isomers.

Author Contributions: Data curation, H.M. and J.B.; investigation, W.J.; writing-original draft, H.M.; writing-review and editing, M.Z., W.J., X.X. and X.L. All authors have read and agreed to the published version of the manuscript.

Funding: This work was supported by the National Natural Science Foundation (grant number 51806205) and the Key Sci-Tech Innovation 2025 Program of Ningbo, China (2018B10025).

Acknowledgments: This article would not have been possible without the consistent and valuable reference materials that I received from my supervisor, to whom I owe the deepest gratitude for the insightful guidance and enthusiastic encouragement in the course of shaping this thesis.

Conflicts of Interest: The authors declare no conflict of interest.

\section{References}

1. Demirbaş, A. Analysis of Liquid Products from Biomass via Flash Pyrolysis. Energy Sources 2002, 24, 337-345. [CrossRef]

2. Chen, D.; Yin, L.; Wang, H.; He, P. Pyrolysis technologies for municipal solid waste: A review. Waste Manag. 2014, 34, $2466-2486$. [CrossRef] [PubMed]

3. Malkow, T. Novel and innovative pyrolysis and gasification technologies for energy efficient and environmentally sound MSW disposal. Waste Manag. 2004, 24, 53-79. [CrossRef]

4. Ferrara, F.; Orsini, A.; Plaisant, A.; Pettinau, A. Pyrolysis of coal, biomass and their blends: Performance assessment by thermogravimetric analysis. Bioresour. Technol. 2014, 171, 433-441. [CrossRef] [PubMed]

5. Guan, Y.; Ma, Y.; Zhang, K.; Chen, H.; Xu, G.; Liu, W.; Yang, Y. Co-pyrolysis behaviors of energy grass and lignite. Energy Convers. Manag. 2015, 93, 132-140. [CrossRef]

6. Chen, W.; Shi, S.; Zhang, J.; Chen, M.; Zhou, X. Co-pyrolysis of waste newspaper with high-density polyethylene: Synergistic effect and oil characterization. Energy Convers. Manag. 2016, 112, 41-48. [CrossRef]

7. Bai, X.J.; Zhang, H.Y.; Wang, G.Q.; Jun, G.U.; Wang, J.H.J.e.e. Research Progress on Comprehensive Utilization of Stale Refuse in Landfill. Environ. Eng. 2018, 36, 43-47. [CrossRef] 
8. Bridgwater, A.V. Review of fast pyrolysis of biomass and product upgrading. Biomass Bioenergy 2012, 38, 68-94. [CrossRef]

9. Zeng, D.; Hu, L.; Lei, M.; Xu, Z.; Dongyang, W. Overview of domestic waste pyrolysis and gasification pollutant generation and emission control technology. Environ. Prot. Circ. Econ. 2018, 38, 17-21.

10. Arena, U. Process and technological aspects of municipal solid waste gasification. A review. Waste Manag. 2012, 32, 625-639. [CrossRef]

11. Dong, J.; Chi, Y.; Tang, Y.; Ni, M.; Nzihou, A.; Weiss-Hortala, E.; Huang, Q.J.E. Partitioning of heavy metals in municipal solid waste pyrolysis, gasification, and incineration. Energy Fuels 2015, 29, 7516-7525. [CrossRef]

12. Wang, Z.; Xie, L.; Liu, K.; Wang, J.; Zhu, H.; Song, Q.; Shu, X. Co-pyrolysis of sewage sludge and cotton stalks. Waste Manag. 2019, 89, 430-438. [CrossRef]

13. Li, H.; Jiang, X.; Cui, H.; Wang, F.; Zhang, X.; Yang, L.; Wang, C. Investigation on the co-pyrolysis of waste rubber/plastics blended with a stalk additive. J. Anal. Appl. Pyrolysis 2015, 115, 37-42. [CrossRef]

14. Hossain, M.S.; Islam, M.R.; Rahman, M.S.; Kader, M.A.; Haniu, H. Biofuel from Co-pyrolysis of Solid Tire Waste and Rice Husk. Energy Procedia 2017, 110, 453-458. [CrossRef]

15. Ma, W.; Hoffmann, G.; Schirmer, M.; Chen, G.; Rotter, V.S. Chlorine characterization and thermal behavior in MSW and RDF. J. Hazard. Mater. 2010, 178, 489-498. [CrossRef]

16. Tuppurainen, K.; Halonen, I.; Ruokojrvi, P.; Tarhanen, J.; Ruuskanen, J. Formation of PCDDs and PCDFs in Municipal Waste Incineration and Its Inhibition Mechanisms: A Review. Chemosphere 1998, 36, 1493-1511. [CrossRef]

17. El-Rub, Z.A.; Bramer, E.A.; Brem, G. Review of catalysts for tar elimination in biomass gasification processes. Ind. Eng. Chem. Res. 2004, 43, 6911-6919. [CrossRef]

18. Lohmann, R.; Northcott, G.L.; Jones, K.C. Assessing the contribution of diffuse domestic burning as a source of PCDD/Fs, PCBs and PAHs to the UK atmosphere. Environ. Sci. Technol. 2002, 34, 2892-2899. [CrossRef]

19. Bhavsar, S.P.; Reiner, E.J.; Hayton, A.; Fletcher, R.; MacPherson, K. Converting Toxic Equivalents (TEQ) of dioxins and dioxin-like compounds in fish from one Toxic Equivalency Factor (TEF) scheme to another. Environ. Int. 2008, 34, 915-921. [CrossRef]

20. Jie, Y.; Sun, L.; Xiang, J.; Song, H.; Su, S. Kinetic vaporization of heavy metals during fluidized bed thermal treatment of municipal solid waste. Waste Manag. 2013, 33, 340-346.

21. Li, Q.; Meng, A.; Jia, J.; Zhang, Y. Investigation of heavy metal partitioning influenced by flue gas moisture and chlorine content during waste incineration. J. Environ. Sci. 2010, 22, 760-768. [CrossRef]

22. Praspaliauskas, M.; Pedisius, N.; Striugas, N. Elemental migration and transformation from sewage sludge to residual products during the pyrolysis process. Energy Fuels 2018, 32, 5199-5208. [CrossRef]

23. Yousif, S.; Lockwood, F.C.; Abbas, T. Modeling of toxic metal emissions from solid fuel combustors. Symp. Combust. 1998, 27, 1647-1654. [CrossRef]

24. Blumenstock, M.; Zimmermann, R.; Schramm, K.W.; Kettrup, A. Influence of combustion conditions on the PCDD/F-, PCB-, PCBz- and PAH-concentrations in the post-combustion chamber of a waste incineration pilot plant. Chemosphere 2000, 40, 987-993. [CrossRef]

25. Idris, S.S.; Rahman, N.A.; Ismail, K.; Alias, A.B.; Aris, M.J. Investigation on thermochemical behaviour of low rank Malaysian coal, oil palm biomass and their blends during pyrolysis via thermogravimetric analysis (TGA). Bioresour. Technol. 2010, 101, 4584-4592. [CrossRef] [PubMed]

26. White, J.E.; Catallo, W.J.; Legendre, B.L. Biomass pyrolysis kinetics: A comparative critical review with relevant agricultural residue case studies. J. Anal. Appl. Pyrolysis 2011, 91, 1-33. [CrossRef]

27. Li, H.W.; Wang, L.C.; Chen, C.C.; Yang, X.Y.; Chang-Chien, G.P.; Wu, M.Y. Influence of memory effect caused by aged bag filters on the stack PCDD/F emissions. J. Hazard. Mater. 2011, 185, 1148-1155. [CrossRef] [PubMed]

28. Ficarella, A.; Laforgia, D. Numerical simulation of flow-field and dioxins chemistry for incineration plants and experimental investigation. Waste Manag. 2000, 20, 27-49. [CrossRef]

29. Raghunathan, K.; Gullett, B.K.J.E.S. Role of sulfur in reducing PCDD and PCDF formation. Environ. Sci. Technol. 1996, 30, 1827-1834. [CrossRef]

30. Luthe, C.; Strang, A.; Uloth, V.; Karidio, I.; Prescott, B. Sulphur addition to control dioxins formation in salt-laden power boilers-Co-firing of CNCGs with salt-laden wood waste is effective. Pulp Pap. Can. 1998, 99, 48-52.

31. Wikström, E.; Ryan, S.; Touati, A.; Telfer, M.; Gullett, B.K. Importance of chlorine speciation on de novo formation of polychlorinated dibenzo-p-dioxins and polychlorinated dibenzofurans. Environ. Sci. Technol. 2003, 37, 1108. [CrossRef]

32. Gullett, B.K.; Bruce, K.R.; Beach, L.O. Effect of sulfur dioxide on the formation mechanism of polychlorinated dibenzodioxin and dibenzofuran in municipal waste combustors. Environ. Sci. Technol. 1992, 26, 1938-1943. [CrossRef]

33. Buekens, H.H. Chemical kinetic modelling of PCDD formation from chlorophenol catalysed by incinerator fly ash. Chemosphere 2000, 41, 943-951.

34. Matsuzawa, Y.; Ayabe, M.; Nishino, J. Acceleration of cellulose co-pyrolysis with polymer. Polym. Degrad. Stab. 2001, 71, 435-444. [CrossRef]

35. Hui, Z.; Meng, A.; Long, Y.; Li, Q.; Zhang, Y. A review of dioxin-related substances during municipal solid waste incineration. Waste Manag. 2015, 36, 106-118.

36. Kuzuhara, S.; Sato, H.; Kasai, E.; Nakamura, T. Influence of metallic chlorides on the formation of PCDD/Fs during lowtemperature oxidation of carbon. Environ. Sci. Technol. 2003, 37, 2431-2435. [CrossRef] [PubMed] 
37. Chang, M.B.; Huang, T.F. The effects of temperature and oxygen content on the PCDD/PCDFs formation in MSW fly ash. Chemosphere 2000, 40, 159-164. [CrossRef]

38. Chang, M.B.; Huang, T.F. Dioxin contents in fly ash from large-scale MSW incinerators in Taiwan. Chemosphere 1999, 39, 2671-2680. [CrossRef]

39. Hatanaka, T.; Imagawa, T.; Takeuchi, M. Effects of copper chloride on formation of polychlorinated dibenzo-p-dioxins in model waste incineration. Chemosphere 2003, 51, 1041-1046. [CrossRef]

40. Huang, H.; Buekens, A. On the mechanisms of dioxin formation in combustion processes. Chemosphere 1995, 31, 4099-4117. [CrossRef] 